\title{
ปรBDIJSA IOTES
}

\section{A Mobile Infiltrometer for Use on Rangeland}

\author{
W. H. BLACKBURN, R. O. MEEUWIG, \\ AND C. M. SKAU
}

Highlight: The mobile drip type infiltrometer described in this note is easily constructed and simple to operate on rangelands accessible by truck.

High intensity summer thunderstorms account for most of the runoff and sediment production from rangelands in the Great Basin. Infiltration and sediment production experiments based on sporadic storm events are very seldom economically feasible. An alternate to natural precipitation is simulated rainfall applied to small plots. This paper describes a drip type infiltrometer used by Blackburn (1973) to measure infiltration rates and sediment production of arid and semiarid rangelands in Nevada.

\section{Infiltrometer Design.}

The infiltrometer is mounted on a two-wheel trailer (Fig. 1). Water is pumped from the 300-gal tank (1) to the elevated 55 gal barrel (2) and flows by gravity through filters and flowmeters (3) to the raindrop-producing modules (4). Modules are suspended 7 $\mathrm{ft}$ above the soil surface on adjustable arms constructed of 3-inch water pipe (5). Simulated raindrops reach about $70 \%$ of terminal velocity at $7 \mathrm{ft}$ (Todd, 1970).

Supporting arms (5) are adjustable from 4 to $8 \mathrm{ft}$ horizontally and modules are raised and lowered by a steel cable and hand winch (6). The modules (4) must be leveled for uniform raindrop distribution by adjusting turnbuckles on guywires (7). Once

Authors are assistant professor of range and watershed management, Renewable Resources Center, University of Nevada, Reno; soil physicist, Intermountain Forest and Range Exp. Sta., Reno, Nevada; and professor of watershed management, Renewable Resource Center, University of Nevada, Reno.

This infiltrometer was developed in cooperation with the Bureau of Land Management and Nevada Agriculture Experiment Station, Journal Series No. 271. The financial support of the Bureau is acknowledged.

Manuscript received October 10, 1973.

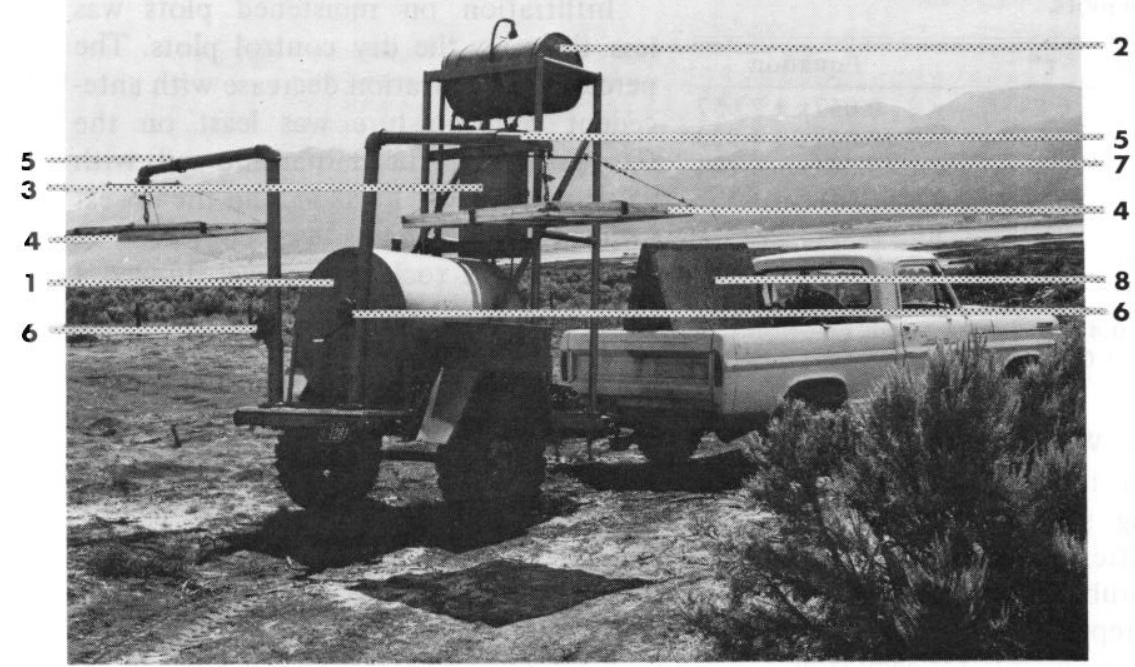

Fig. 1. Infiltrometer.

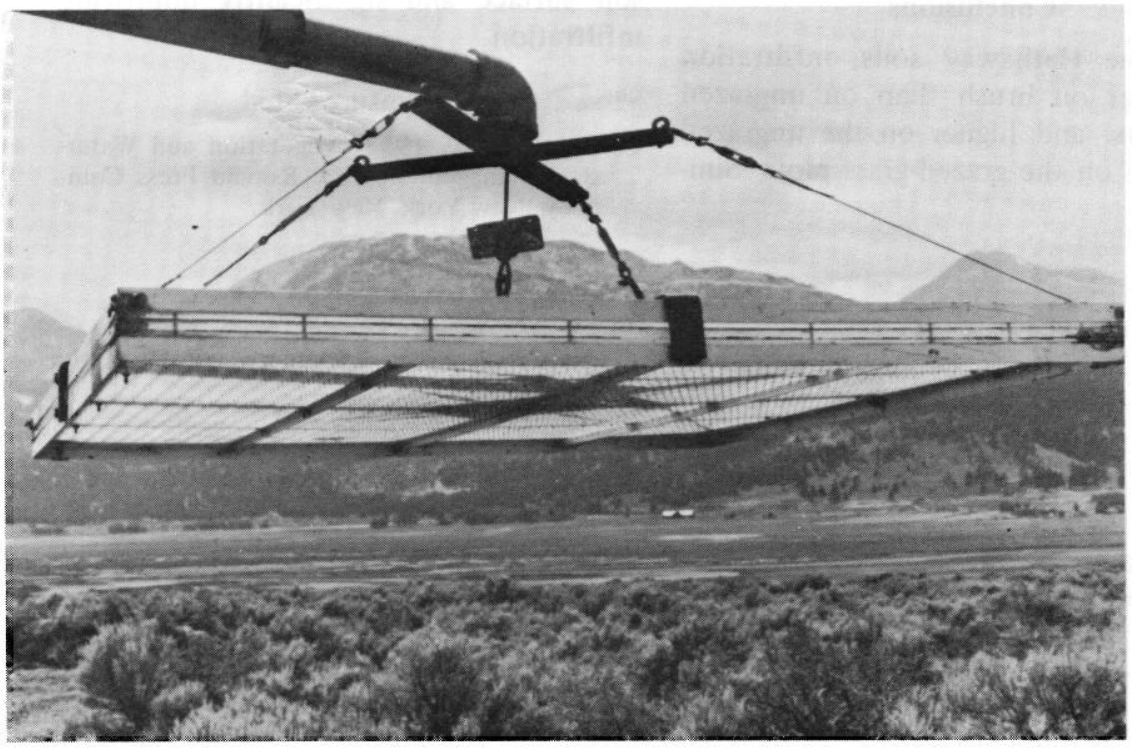

Fig. 2. Raindrop-producing module.

adjusted, the guywires seldom require readjustment.

The raindrop-producing module (Fig. 2) is similar to the one originally described by Chow and Harbough (1965) and to modified versions of it described by Timko and Skau (1967) and Meeuwig (1971). The module consists of two 4- by 4-ft sheets of 1/4inch plexiglass spaced 1/2-inch apart, sealed with caulking compound, and bolted to angle aluminum. Each module has 2,209 tubes $^{1}$ at 1-inch spacing that project $1 / 4$ inch above and $1 / 4$ inch below the lower plexiglass sheet. These tubes are 23 gauge stainless steel, 3/4-inch long and have

${ }^{1}$ Obtained from Vita Needle Co., Needham, Mass. 02192. 


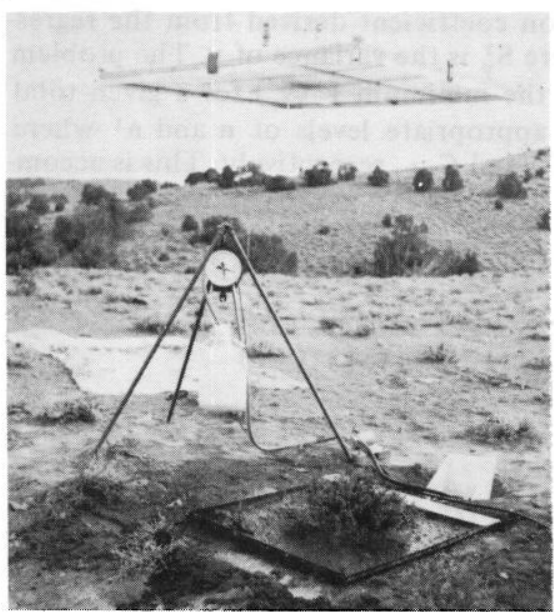

Fig. 3. Standard plot frame.

an inside diameter of 0.01875 inch. Epoxy cement holds the tubes in place. Rainfall intensities of about 0.2 inch per hour to about 3.3 inches per hour can be simulated with the Manostat (Cat. No. 36-541-30) flowmeter used. The modules are strapped to the Aframe (8) when transported.

Wind shelters, similar to those used by Dortignac (1951), are usually necessary to avoid excessive drift of simulated raindrops.

The standard plot frame (Fig. 3) 3by 3 -ft or variable size plot frame (Fig. 4) is driven about 1 inch into the soil. The collector trough at the bottom is covered with a sheet of plexiglass to prevent simulated rain from falling directly into the trough. Runoff is piped into a small pail, then pumped with a 12-volt pony pump into a 5-gal polyethylene bottle on a spring scale.

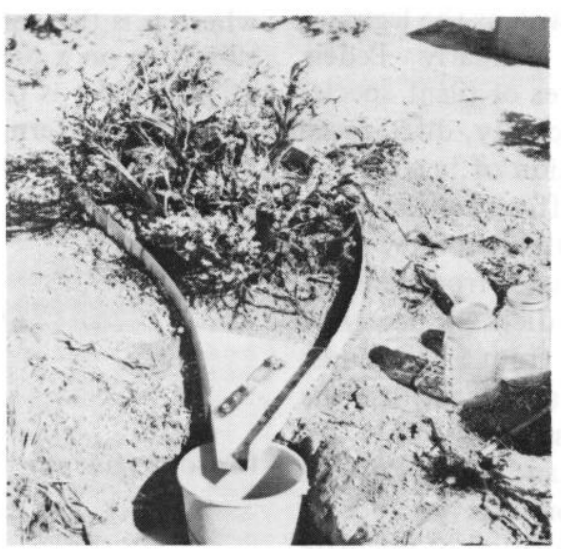

Fig. 4. Variable size plot frame.

Runoff is weighed at fixed intervals for conversion to inches of runoff.

\section{Operation}

The plots are placed at selected intervals and covered with polyethylene plastic to keep the plot dry while setting up and filling the modules. Modules are attached to the adjustable arms, leveled and centered over the plots. After the chambers are filled with water and desired flow rate set, the plot covers are removed. Two plots are easily run at the same time. The flow rate will stay constant if the filters are replaced regularly and the 55 -gal tank is kept relatively full. However, the flow meters should be checked periodically.

Water was obtained from springs, small streams, or livestock watering troughs. Clogging of the steel tubes was largely prevented by passing the water through Aqua-pure P111 filters.
When clogging did occur, it was easily cleaned by pushing a small steel wire up the bore.

Sediment production can be determined from runoff at the end of the test. After each test, sediment trapped in the system is collected along with a $900 \mathrm{ml}$ thoroughly mixed sample of runoff from the 5-gal polyethylene bottle. Suspended sediment is allowed to settle in the laboratory and the water decanted. Samples are then oven dried, weighed and converted to tons per acre sediment.

More specific information on the construction and operation of the infiltrometer can be obtained from the authors.

\section{Literature Cited}

Blackburn, W. H. 1973. Simulated rainfall studies of selected plant communities and soils in five rangeland watersheds in Nevada. PhD Diss., Univ. of Nev., Reno. $152 \mathrm{p}$.

Chow, V. T., and T. E. Harbaugh. 1965. Raindrop production for laboratory watershed experimentation. J. Geophysical Res. 70(24): 6111-6119.

Dortignac, E. J. 1951. Design and operation of Rocky Mountain infiltrometer. U. S. Dep. Agr. Forest Serv., Rocky Mountain Forest and Range Exp. Sta. Paper No. 5 $68 \mathrm{p}$.

Meeuwig, R. O. 1971. Infiltration and water repellency in granitic soils. U. S. Dep. Agr. Forest Serv., Res. Paper INT-111. $20 \mathrm{p}$.

Timko, S. T., and C. M. Skau. 1967. A low intensity rain simulator for long duration rain-on-snow events. Proc. of the Third National Amer. Water Conf.

Todd, D. K. 1970. The water encyclopedia. Water information Center, Port Washington, N. Y. 559 p. 